\title{
Factors influencing conative loyalty in anthropology museum tourism
}

\section{Fatores que influenciam a lealdade conativa no turismo de museus de antropologia}

\author{
JingJing Zheng
}

School of Foreign Languages for Business, Guangxi University of Finance and Economics and Faculty of International Tourism and Management, City University of Macau, j___zheng_gxufe@163.com

Huawen Shen

Faculty of International Tourism and Management, City University of Macau, jamesshen@cityu.mo

\section{Ka Yin Chau}

Faculty of Business, City University of Macau, gavinchau@cityu.mo

Ting Liu

Economic and Trade College, Guangxi University of Finance and Economics and Faculty of International Tourism and Management, City University of Macau, tingliu_@hotmail.com

\section{EnLong Li}

Faculty of International Tourism and Management, City University of Macau, Liszt2022@126.com

Received: 11.09.2020; Revisions required: 16.12.2020; Accepted: 04.03.2021

\section{Abstract}

Although service quality and customer satisfaction have been frequently discussed by scholars in tourism research, their connections with emotional factors have rarely been investigated in a museum context. The Anthropology Museum of Guangxi focuses on unique ethnic minorities, which is used as the case study in this paper. This study examines the relationships among the factors that influence visitors' emotional attachment, satisfaction, conative loyalty, and perceived quality. Structural equation modeling (PLS-SEM) was used to model the relations among these four constructs, a 184-visitor sample is assessed, and the conceptual model supports all the proposed hypotheses. The results show positive influences among emotional attachment, visitor satisfaction, and perceived quality, which may indeed affect visitors' conative loyalty to a specific museum. The practical applications are suggested based on findings that the conative loyalty of museum visitors is relatively influenced by their emotional connection and that emotional arousal can promote the acceptance of museum tourism.

Keywords: Emotional attachment, Perceived quality, Visitor satisfaction, Conative loyalty, Anthropology Museum tourism.

\section{Resumo}

Embora a qualidade do serviço e a satisfação do cliente tenham sido frequentemente discutidas na investigação turística, as suas conexões com fatores emocionais raramente têm sido investigadas num contexto de museu. O Museu de Antropologia de Guangxi foca-se em minorias étnicas únicas, e é usado como estudo de caso neste artigo. Este estudo examina as relações entre os fatores que influenciam o apego emocional, a satisfação, a lealdade conativa e a qualidade percebida dos visitantes. A modelagem de equações estruturais (PLS-SEM) foi utilizada para modelar as relações entre esses quatro construtos, tendo sido avaliada uma amostra de 184 visitantes do museu. O modelo conceitual suporta todas as hipóteses propostas. Os resultados mostram influências positivas entre o apego emocional, a satisfação dos visitantes e a qualidade percebida, o que pode de fato afetar a lealdade conativa dos visitantes a um museu específico.

Palavras-chave: Apego emocional, Qualidade percebida, Satisfação do visitante, Lealdade conativa, Turismo em museus de antropologia.

\section{Introduction}

With the universal implementation of the reform and openingup policy in China and increasing public interest in culture and education, museums have become popular tourist stops. In this new era of culture and tourism integration, how can museums, as highly concentrated institutions of cultural resources, better play the role of passing on civilization and culture to the next generation? Several museums, travel agencies, and educational institutions have established businesses around museum resources through research tours, project studies, group tours, and so forth, as part of new cultural and tourism integration projects. Thus, the museum tourism industry is becoming a vital educational part of the tourism industry. As aplicações práticas são sugeridas com base nos resultados de que a lealdade conativa dos visitantes do museu é relativamente influenciada pela sua conexão emocional e que a excitação emocional pode promover a aceitação do turismo de museus.

The International Council of Museums (ICOM) (Boylan, 2010) defines a museum as a non-profit, permanent institution serving the development of society, which is open to the public, and focuses on the preservation, research, dissemination and exhibition of physical evidence of people and their environment for the purposes of research, education and enjoyment. The museum environment provides researchers with unique backgrounds to explore service quality standards. In a museum, unlike other tourism destinations, what matters is not achieving 
the greatest profits or most effective management. Because of its unique qualities, a museum's stakeholders are more concerned about the collection than visitors' needs.

However, does visitors' satisfaction and loyalty not matter for the museum industry at all? According to McLean (1994), many museum marketers believe that customers are essential in their organization's success. As the importance of museum visitors is now recognized, the museum industry has begun to consider the factors involved. If marketers can relate these factors to the loyalty of visitors, the profitability of museums may rise. The next problem to be solved is how to maintain visitor loyalty. As Simpson and Seeger (2008) observe, many factors contribute to increasing or decreasing public interest in museums. Word-ofmouth promotion is a type of positive information that comes from friends and family members. This source of information is trustworthy as it displays an honest impression of tourists. Museums have an obligation to attract visitors, not only those who are wealthy or the "person most likely to be involved" (Parliament of Victoria, 1983) but also those who may be 'loyal' to the organization. Reimer and Kuehn (2005) show that museum visitors pay significant attention to the service environment, the service process in particular. For example, Raajpoot, Koh, and Jackson (2010) propose that in assessing a museum visit, visitors may consider physical aspects, such as the exhibitions or the building and also make a holistic evaluation. Furthermore, this impression is constructed based on quality perceived by tourists. In China's museum industry, cultural content is important for museum projects, and the catchphrase is 'content is king'. For instance, the Suzhou Museum provides different services for children, teenagers, the elderly, and professionals. It does not rely only on Bei Yuming's architecture to attract tourists; museum stakeholders believe that content makes the difference in the long run. However, as visitors participate in museum tourism for different purposes, it is unknown whether emotional attachment is one of the factors that motivate visitors. By arranging tours or designing content based on emotional experience, a museum can allow the visitor to relive the past or reexperience events, enabling them to feel anticipation, shock, sadness, anger, inspiration, and peace and strength.

Thus, it seems that the relationship between quality, satisfaction, and loyalty can be identified in the museum domain, just as in other sectors of the tourism industry. However, little evidence in the tourism context exists to show a causal relationship between loyalty and emotional attachment in the museum tourism context. The objectives of this research are: 1 ) to develop a model of perceived service quality, visitor satisfaction, and conative loyalty in the museum domain; 2) to emphasize the importance of emotional attachment in the model and further identify the relationship between emotional attachment, perceived quality, visitor satisfaction, and the conative loyalty of museum visitors; 3 ) to discuss the effects of emotional attachment and conative loyalty on the museum and its visitors, and to further reveal the role and impact of emotional communication on the cultural communication of museums, and provide empirical support for practitioners. This study focuses on the case of the Anthropology Museum of Guangxi (AMGX). AMGX is dedicated to Zhuang culture. It is a large, first-class national museum with an area of 33,000 square meters.

Currently, it holds a collection of 35,000 pieces (sets) of ancient bronze drums, national costumes, brocade embroidery, tools, folk arts and crafts, and folk houses. Six permanent exhibitions exist: Bronze Drum Culture; Colourful Guangxi-Guangxi Ethnic Culture; Zhuang Culture; Chinese Culture for Different Nationalities; Colourful World-The International Ethnic Culture Collection; and Yesterday Once More-Century Old Items. The museum is the national cultural and educational base of the government and the university and receives visitors from all over the world. As it is in Nanning, the capital of Guangxi, it is a popular choice for sightseeing.

This study aims to compare the effects of emotional attachment, visitor satisfaction, and perceived quality on conative loyalty. It provides valuable managerial and academic implications for studying museum tourism because these relationships have not been previously systematically evaluated in the museum industry. Partial least squares structural equation modeling (PLS-SEM) was used to analyze the model. Based on a review of the literature on emotional attachment $(E A)$, perceived quality (PQ), visitor satisfaction (VS), and communicative loyalty $(\mathrm{CL})$ and the relationships among these concepts, we propose the following research hypotheses and conceptual framework (Figure 1).

Figure 1 - Theoretical framework of the research

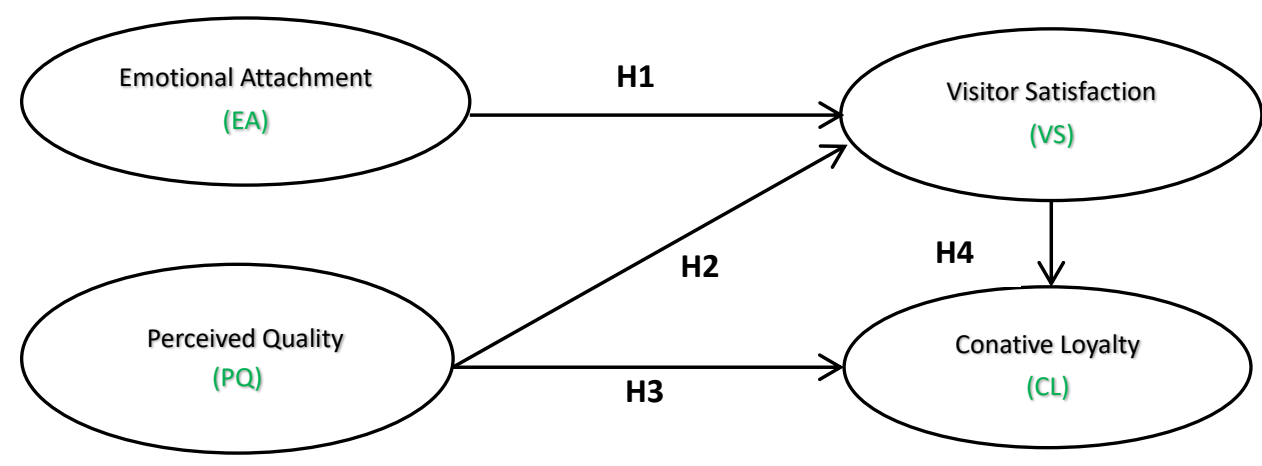


- Hypothesis 1 (H1): Emotional attachment positively influences visitor satisfaction ( $E A \rightarrow V S$ )

- Hypothesis 2 (H2): Perceived quality positively influences visitor satisfaction $(\mathrm{PQ} \rightarrow \mathrm{VS})$.

- Hypothesis $\mathbf{3}$ (H3): Perceived quality has a direct positive effect on conative loyalty $(\mathrm{PQ} \rightarrow \mathrm{CL})$.

- Hypothesis 4 (H4): Visitor satisfaction has a direct positive effect on conative loyalty (VS $\rightarrow \mathrm{CL}$ ).

- Hypothesis 5 (H5): Emotional attachment has a mediating effect on the correlation between perceived quality and conative loyalty $(\mathrm{EA} \rightarrow \mathrm{VS} \rightarrow \mathrm{CL})$.

- Hypothesis 6 (H6): Visitor satisfaction has a mediating effect on the correlation between perceived quality and conative loyalty $(\mathrm{PQ} \rightarrow \mathrm{VS} \rightarrow \mathrm{CL})$.

This study is structured as follows. First, a literature review of the four fundamental concepts, $E A, V S, P Q$, and $C L$, is presented. Second, the methodology is outlined, including the data collection procedure and PLS-SEM testing. Next, the test results are analyzed and discussed. The theoretical and managerial implications and the research limitations of this study are covered in the final section.

\section{Literature review}

\subsection{Emotional attachment}

The National September 11 Memorial and Museum (9/11 memorial museum) is famous for its emotional impact. The exhibition expresses the heartrending emotions of people in New York and across the United States. The emotional design of the 9/11 museum elicits visitors' emotions, conveys a large amount of information, and leads them to a final sense of peace. This complete emotional design not only achieves the goal of presenting the $9 / 11$ event as completely as possible to visitors quickly but also enables them to smoothly return to real life after the experience. As Hsieh (2010) remarks, museum practitioners should focus on push and pull motivation for stimulating visitors' willingness to visit. To illustrate, establishing an attachment for visitors is crucial to a museum's successful design.

The idea of attachment was first proposed by British psychiatrist John Bowlby. Until the late 1980s, research on attachment theory mostly focused on children. Attachment theory presents ideas and concepts that concern the formation, preservation, and elimination of intimate relationships among human beings (Bartholomew \& Horowitz, 1991; Hazan \& Shaver, 1994). However, psychological and marketing research has demonstrated that attachment can extend to many other areas, including inter- and intrapersonal relationships (Thomson and Johnson, 2006), regions or destinations (Williams \& Vaske, 2003; Moore \& Graefe, 1994), objectives or properties (Kleine \& Baker, 2004; Ball \& Tasaki, 1992), and enterprises or brands (Carroll \& Ahuvia, 2006; Paulssen \& Fournier, 2007; Park \& Maclnnis, 2006). Recently, emotional attachment theory has been widely applied to the marketing sector (Thomson \& Johnson, 2006). Paulssen and Fournier (2007) empirically showed that similar behavior patterns occur within business and interpersonal relationships. To discuss emotionally aroused attachment, the term "emotional attachment" was coined by Thomson (2006) and Thomson, Maclnnis, and Park (2005). However, Albert, Merunka, and Valette-Florence (2008) adopted the word "love".

Despite differences in terminology, the main findings of several studies suggest that consumers can develop solid emotional bonds in business relationships. Blackston (1992) first proposed the concept of brand relationship and believes that brand relationship is a two-way communication between the perception of a certain brand and the reflection of the brand for customers. Paulssen and Fournier (2007) observed that, in the automobile service industry, personal safety attachment promotes stronger business relationships. Albert et al. (2008) summarized 11 dimensions of love in the consumer-brand relationship. The theoretical basis of the definition of attachment is social cognition theory, particularly the selfconcept theory, which regards attachment as representing the degree to which individuals develop and maintain a selfcognition structure.

The Destination Emotion Scale (DES) was developed by Hosany and Gilbert (2010) to measure the diversity and strength of visitors' emotional experiences towards a place. In environmental psychology (e.g., Hidalgo \& Hernandez 2001; Williams \& Vaske 2003) and tourism literature (e.g., Lee, Kyle, \& Scott 2012; Yuksel, Yuksel, \& Bilim, 2010), two major types of destination emotional conceptualization dominate: emotional and functional attachment. Currently, emotional attachment is defined as the emblematic meaning of a place as an emotional repository with implications for one's life (Giuliani \& Feldman, 1993). The existence of a personal history between consumers and brands is essential for emotional attachment (Belk, 1988), and satisfaction may only come from a few consumption experiences.

\subsection{Visitor satisfaction}

Many customer satisfaction theories in the literature exist: anticipation-disconfirmation, absorption, comparability, absorption-comparability, fairness, achievement, comparisonlevel, generalized negativism, and value-recognition (Oh \& Parks, 1997). The Anticipation-Disconfirmation Paradigm (ADP) is most frequently used in research on satisfaction. The ADP focuses on the perceiver's comparison between anticipated and real experiences, which can have three results: confirmation, positive disconfirmation, or negative disconfirmation (Oliver, 1980). In the tourism context, the first and second results mean that the visitor is satisfied with the travel experience, whereas negative disconfirmation means that the visitor is unsatisfied. Although ADP is a generally accepted model, the inclusion of expectations in the satisfaction scale remains disputed. The ADP assumes that people have firm expectations before going to a destination because without prior anticipation, tourists cannot experience confirmation or disconfirmation (Yüksel \& Yüksel, 
2001). Brucks, Zeithaml, and Naylor (2000) argued that this hypothesis is not suitable for the travel context, as travel products are based more on experience and trust attributes than on search attributes.

While many studies involving satisfaction relate to tourism context, some scholars have also turned their attention to museums. Sulkaisi and Idris (2020) demonstrate the relationship of overall visitor satisfaction, service quality, and loyalty by applying data collected from the Adityawarman Museum. Visitors may not have many expectations of museums, as they visit them infrequently. In addition, by establishing the dimensions of service quality and using the multilevel model as the framework, Wu and Li (2015) consider Macau Museum visitors as research objects for further exploring the influence of service quality on emotions. The behavioral intention generated by the influence of comprehensive emotion and service quality on visitor satisfaction are also illustrated. Vesci, Conti, Rossato, and Castellani (2020) examined the mediating effect of satisfaction by studying the relationship between museum visitor quality of experience and WOM behavior in the Italian Museum. Siu, Zhang, Dong, and Kwan (2013) proposed the importance of new service bonds as well as its connections with customer value, which further influences the sustainable development of the museum industry.

\subsection{Perceived quality}

Because of rapid social and economic development, the concept of "quality" has continued to be enriched, improved, and widened. Quality can be defined as the degree to which an object's the intrinsic features meet the user's requirements. The idea of service quality has prompted extensive research, such as the application of the evaluation tool SERVQUAL, which was introduced in the 1980s (Parasuraman, Zeithaml, \& Berry, 1988). SERVQUAL evaluates five service quality levels: tangibles, reliability, responsiveness, assurance, and empathy, with a set of questions for each level. Survey respondents answer each question in terms of expectations, true feelings, and minimum acceptance. Recent research shows that SERVQUAL can predict service quality and suggest development initiatives. Since its development, experts and scholars in the service and tourism industries have widely used it (Armstrong, Mok, Go, \& Chan, 1997; Atilgan, Akinci, \& Aksoy, 2003; Hui, Wan, \& Ho, 2007; Hsieh, Lin, \& Lin, 2008). Lee, Petrick, Crompton (2007) highlighted that the service quality of a group can better predict the behavioral intention of tourists than the notion of quality as simply overall advantage or superiority. Perceived quality commonly refers to consumers' comprehensive experience of the advantages of a brand compared with comparable goods and determines the influence assessment ratio of the brand. Perceived quality is also associated with brand perception. If the original product is popular among consumers, accepting derivative products is easier for them. Consumers' involvement and experience should be prioritized to improve product perception. For the service industry, Gronroos (1982) proposes the customer perceived service quality model to define customers' evaluation of service quality, wherein consumers compare their authentic feelings and expectations towards a service. If expectations are satisfied, their feelings are positive, and vice versa. Gotlieb, Grewal, and Brown (1994) considered models from different causative perspectives and found that service quality can affect satisfaction level and that the latter also influences consumers/visitors' willingness (Taylor \& Baker, 1994).

\subsection{Conative loyalty}

Copeland was the first to introduce the notion of loyalty into tourism studies in 1923 (Sun, Chi, \& Xu, 2013). However, loyalty remains a frequent subject of debate among scholars (Kim \& Brown, 2012; Weaver \& Lawton, 2011) and is considered a significant indicator of the prosperity of the tourism industry. A loyal attitude means that an individual wishes to keep developing a connection with a service or product supplier, whereas loyal behavior is a person's sustained support of a place or product (Morais \& Lin, 2010). In the context of museum, the relationship between the loyalty formation process and the internal and external dimensions of the physical environment are proposed by Han and Hyun (2019) in museum research and demonstrates the mediating role of museum visitors' cognition, evaluation, and motivation factors.

Various methods can be used to define and measure loyalty (Jacoby \& Chestnut, 1978). Visitor loyalty is defined as the connection between a single visit and repeat visits (Dick \& Basu, 1994). In recent studies, scholars have analyzed behavioral intention using a cognitive-emotional framework (e.g., Lam, Shankar, Erramilli, \& Murthy, 2004; Oliver, 1999), with theoretical support based on Bagozzi's (1992) model of the selfregulation mechanism.

George and George (2004) use "how often and how much past buying" and "willingness to travel again" as substitutes for loyalty when studying the mediating effect of attachment on destination loyalty. Kyle, Graefe, Manning, \& Bacon (2004) use "the number of days spent, the number of miles traveled, and the proportion used" to replace behavioral loyalty. According to Simpson and Siquaw (2008), public praise conveying willingness is one factor in loyalty. Oliver (1999) holds that loyalty research should focus on three stages: first, a special fondness for rival brand characteristics; second, an emotional and attitudinal preference for a product; and third, greater willingness to buy the product over competing products. Initially, consumers' loyalty to a service occurs through recognition, then involves an emotional "like" or "don't like" response, and, finally, a conative feeling of "like" or "don't like" (Back, 2005; Oliver, 1997). Therefore, the loyalty and commitment of tourists to a service supplier is established gradually at each loyalty stage. According to Oliver (1999), tourists can remain loyal at each stage of an attitude expedition framework comprising diverse factors. Loyalty is affected by multiple elements during different loyalty phases (Evanschitzky \& Wunderlich, 2006). Buyers will be emotionally loyal to a product if they have a positive attitude 
toward it. Compared with cognition, emotion more deeply influences consumers and is less easily refuted (Oliver, 1997). Pedersen and Nysveen (2001) argue that behavioral loyalty cannot be completely predicted by emotional loyalty, although emotion is more powerful than cognition. Buyers pleased with a product in a service classification may have emotional loyalty to other brands in the same classification. Conative loyalty, one of the three most powerful factors, may increase behavioral loyalty more than cognition and willingness (Pedersen \& Nysveen, 2001). Pedersen and Nysveen (2001) define it as consumers' willingness to continue using the brand later.

\section{Methodology}

\subsection{Questionnaire design}

The study adopts a quantitative research method, a questionnaire, which is used to obtain results. The survey measured respondents' demographic variables, emotional attachment attributes, perceived quality, visitor satisfaction, and conative loyalty. It focused on evaluating visitors' experiences relative to destination loyalty. The last part of the questionnaire included questions on the background of respondents, such as income, gender, occupation, and so on.

The scale items are listed in Table 3. These scales were adopted from previous studies and measured on a five-point Likert scale, from 1 (the most negative rating) to 5 (the most positive). The experts from this museum verified the validity and consistency of the contents for both original English and Chinese scale visions. These researchers are fully qualified to examine both content accuracy and language proficiency. The items from the scale of Williams and Vaske (2003) were used to measure emotional attachment with some adaptation: "AMGX is a really special place to me"; "I identify very strongly with this museum"; "AMGX means a lot to me"; and "I am strongly attached to this museum." The items used for measuring service were taken from McLean (1997) and Akama and Kieti (2002) and the items discussing the product from PhaswanaMafuya and Haydam (2005) and Rowley (1999). Visitor satisfaction and conative loyalty were tested using other methods. Visitors' satisfaction with the overall museum experience was measured using two items coming from Oliver (1997), which were "I was pleased with my tour of this museum" (abbreviated as PLZ) and "visiting this museum was a wise choice" (CHO). In addition, two items used to measure conative loyalty were taken from Zeithaml, Berry, and Parasuraman (1996): "I will visit this museum again in the next few years" (REV) and "I will recommend this destination to my friends and relatives" (WOM).

In the last part of the questionnaire, a categorical scale was used to record the sociodemographic characteristics and tourism- related habits of the respondents. The variables included their occupation, whether they visited the museum alone or in a group, their ethnicity, local/nonlocal residence, and so on. A pilot study was conducted using a questionnaire. The main purpose of the pilot testing was for eliminating potential problems based on a small sample (Malhotra, 2004). According to Wong and Ko (2009), reliability can be improved by a pilot study, and the appropriateness of data collection instruments can be ensured. Malhotra (2004) states that a sample of 15 to 30 cases is ideal for a pilot study. The sample size of the pilot study was 40 randomly chosen museum visitors.

\subsection{Data collection}

Domestic visitors (local and nonlocal) were the target group in this research. The questionnaire was applied using quota sampling at AMGX (Table 1). On November 14, 2019, 300 questionnaires were personally distributed at the exit of AMGX. A total of 184 valid questionnaires were obtained, giving an effective response rate of $61.3 \%$. To prevent misunderstanding among the respondents, we offered on-site instruction on completing the questionnaire.

\subsection{Analysis design}

The research model was evaluated using the partial least squares (PLS) structural equation modeling technique and SPSS Statistics technique. PLS is highly appropriate for this study as it offers accurate estimates of the impact of interactions, with minimal restrictions on the size of the sample, measurement scale, and distribution of residuals.

A single factor was used to estimate the constructs, and data are often distributed abnormally (Booker \& Serenko, 2007). According to Haenlein and Kaplan (2004), the variance of dependent variables can be maximized by PLS and can then be estimated by independent variables. In this study, SmartPLS 3.2 was used to test the constructs and relationships, and SPSS20.0 was used for tasting the normality distribution of variables.

\section{Findings}

\subsection{Sample characteristics}

The characteristics of the respondents are presented in Table 1. Almost as many women (50.54\%) as men (49.46\%) participated in the survey. More local than nonlocal people (53.80\%) were included, and the majority of respondents were in the 18-30 age group (39.13\%). A total of $39.67 \%$ had a diploma or degree. The majority were of Han nationality (71.20\%), and most were employed (51.63\%). Most of the respondents (82.61\%) visited the museum with friends. The distribution of the samples was in relative equilibrium. 
Table 1 - Sample characteristics

\begin{tabular}{|c|c|c|c|}
\hline & & Frequency & Percentage \\
\hline \multirow{2}{*}{ Gender } & Male & 91 & $49.46 \%$ \\
\hline & Female & 93 & $50.54 \%$ \\
\hline \multirow{4}{*}{ Education } & Secondary & 34 & $18.48 \%$ \\
\hline & Diploma & 73 & $39.67 \%$ \\
\hline & Bachelor & 51 & $27.71 \%$ \\
\hline & Masters or above & 26 & $14.13 \%$ \\
\hline \multirow{3}{*}{ Ethnicity } & Han & 131 & $71.20 \%$ \\
\hline & Zhuang & 34 & $18.48 \%$ \\
\hline & Other & 19 & $10.33 \%$ \\
\hline \multirow{4}{*}{ Employment } & Student & 57 & $30.98 \%$ \\
\hline & Employed & 95 & $51.63 \%$ \\
\hline & Retired & 24 & $13.04 \%$ \\
\hline & Individual household & 8 & $4.35 \%$ \\
\hline \multirow{3}{*}{ Group size } & Went alone & 11 & $5.98 \%$ \\
\hline & Went with relatives & 21 & $11.41 \%$ \\
\hline & Went with friends & 152 & $82.61 \%$ \\
\hline \multirow{2}{*}{ Local/Non-local } & Local & 99 & $53.80 \%$ \\
\hline & Non-local & 84 & $45.65 \%$ \\
\hline
\end{tabular}

\subsection{Reliability and construct validity}

The loadings of the model by PLS are shown in Tables 2 and 3, and the construct reliability (CR) and average variance extracted (AVE) are also presented as the loadings of the measurement model. The reliability of all constructs is higher than 0.70 . The value of $C R$ for each construct was greater than 0.80 , and the value of AVE for each construct was greater than 0.50 . The Cronbach's alpha ranged from 0.733 to 0.856 . These figures indicate that the variance in the constructs to measure error is enough (Fornell and Larcker, 1981).

Table 2 - Reliability and validity of the constructs

\begin{tabular}{|l|c|c|c|c|c|c|}
\hline & Mean & Std. Dev. & Cronbach's Alpha & CR & AVE & PLS loading \\
\hline SI1 & 3.755 & 0.95 & 0.756 & 0.836 & 0.505 & 0.658 \\
\hline SI2 & 3.723 & 1.034 & & & & 0.756 \\
\hline SE1 & 4.304 & 0.811 & & & & 0.717 \\
\hline SE2 & 4.277 & 0.769 & & & & 0.755 \\
\hline PF & 3.935 & 0.864 & & & & 0.663 \\
\hline PLZ & 4.168 & 0.833 & 0.733 & 0.882 & 0.789 & 0.878 \\
\hline CHO & 4.174 & 0.886 & & & & 0.898 \\
\hline REV & 3.745 & 1.163 & 0.739 & 0.884 & 0.792 & 0.905 \\
\hline WOM & 3.848 & 0.972 & & & & 0.874 \\
\hline EA1 & 3.832 & 1.063 & 0.856 & 0.902 & 0.697 & 0.863 \\
\hline EA2 & 3.853 & 1.035 & & & & 0.880 \\
\hline EA3 & 3.908 & 1.009 & & & & 0.755 \\
\hline EA4 & 3.918 & 0.949 & & & & 0.837 \\
\hline
\end{tabular}

Note: All loading values are significant at $p<.050$.

Table 3 - Measurement model

\begin{tabular}{|l|c|l|}
\hline \multicolumn{1}{|c|}{ Factor } & Indicator & \\
\hline Perceived Quality & SI1 & Staff are willing to assist me \\
\hline & SI2 & Staff meet their promises on time \\
\hline & SE1 & Clear sign posting and directions \\
\hline & SE2 & Comfortable environment (temperature, lighting and air, etc.) \\
\hline & PF & Easy to understand exhibitions \\
\hline Visitor Satisfaction & PLZ & I was pleased with my visit to this museum. \\
\hline & CHO & Visiting this museum was a wise choice. \\
\hline Conative Loyalty & REV & I will revisit this museum in the next few years. \\
\hline
\end{tabular}




\begin{tabular}{|l|c|l|}
\hline Factor & Indicator & \\
\hline & WOM & I will recommend this museum to my friends and relatives. \\
\hline Emotional Attachment & EA1 & Anthropology Museum of Guangxi is a very special destination to me. \\
\hline & EA2 & I identify strongly with this destination. \\
\hline & EA3 & AMGX means a lot to me. \\
\hline & EA4 & I am very attached to this museum. \\
\hline
\end{tabular}

The results of PLS loadings are showed in Table 2. The value of $\mathrm{PF}$ and SI 1 are below 0.70 and above 0.40 ( $\mathrm{PF}=0.663$, SI1=0.658), which should be removed from the construct of perceived quality (Hair, Ringle, \& Sarstedt, 2011). After removing the PF and SI1 from perceived quality, results are presented in Table 4, and the value of CR and AVE for perceived quality are both lower than before ( $C R=0.820, A V E=0.598)$. The value of Cronbach's Alpha for perceived quality is 0.664 (smaller than 0.70 ), showing that the variance in the constructs is inadequate for measuring error (Fornell and Larcker, 1981).Thus, the indicators PF and SI1 can be retained in the construct (Hair et al., 2011).

Table 4 - Modified reliability and validity of the constructs

\begin{tabular}{|c|c|c|c|c|c|c|}
\hline & Mean & Std. Dev. & Cronbach's Alpha & CR & AVE & PLS loading \\
\hline SI2 & 3.723 & 1.034 & 0.664 & 0.820 & 0.598 & 0.764 \\
\hline SE1 & 4.304 & 0.811 & & & & 0.746 \\
\hline SE2 & 4.277 & 0.769 & & & & 0.809 \\
\hline PLZ & 4.168 & 0.833 & 0.733 & 0.882 & 0.789 & 0.877 \\
\hline CHO & 4.174 & 0.886 & & & & 0.899 \\
\hline REV & 3.745 & 1.163 & 0.739 & 0.884 & 0.792 & 0.904 \\
\hline WOM & 3.848 & 0.972 & & & & 0.877 \\
\hline EA1 & 3.832 & 1.063 & 0.856 & 0.902 & 0.697 & 0.863 \\
\hline EA2 & 3.853 & 1.035 & & & & \\
\hline EA3 & 3.908 & 1.009 & & & & 0.880 \\
\hline EA4 & 3.918 & 0.949 & & & & 0.835 \\
\hline
\end{tabular}

The normality test is shown in Table 5 and estimated using SPSS 20.0. The K-S test is used to evaluate the normality distribution, as the sample size is greater than 50 ( Lilliefors, 1967; Drezner \& Zerom, 2010). The $p$ values of all indicators are smaller than 0.05 , indicating an abnormal distribution. However, the absolute values of skewness for all indicators are smaller than 3 , and the absolute values of kurtosis of all indicators are less than 10 , which is considered a normal distribution( Lilliefors, 1967; Drezner, \& Zerom, 2010).

Table 5 - Normality test

\begin{tabular}{|c|c|c|c|c|c|c|c|c|c|}
\hline \multirow{2}{*}{ Items } & \multirow{2}{*}{$n$ 司 } & \multirow{2}{*}{ Mean } & \multirow{2}{*}{ Std. } & \multirow{2}{*}{ Skewness } & \multirow{2}{*}{ kurtosis } & \multicolumn{2}{|c|}{ Kolmogorov-Smirnov test } & \multicolumn{2}{|c|}{ Shapro-Wilk test } \\
\hline & & & & & & Statistic $D$ & $p$ & Statistic $W$ & $p$ \\
\hline SI1 & 184 & 3.755 & 0.952 & -0.106 & -1.042 & 0.216 & $0.000^{* *}$ & 0.863 & $0.000^{* *}$ \\
\hline $\mathrm{SI} 2$ & 184 & 3.723 & 1.037 & -0.165 & -1.185 & 0.197 & $0.000^{* *}$ & 0.86 & $0.000 * *$ \\
\hline SE1 & 184 & 4.304 & 0.813 & -0.983 & 0.28 & 0.298 & $0.000^{* *}$ & 0.773 & $0.000^{* *}$ \\
\hline SE2 & 184 & 4.277 & 0.771 & -0.74 & -0.244 & 0.282 & $0.000^{* *}$ & 0.79 & $0.000^{* *}$ \\
\hline $\mathrm{PF}$ & 184 & 3.935 & 0.866 & -0.486 & -0.402 & 0.253 & $0.000^{* *}$ & 0.852 & $0.000 * *$ \\
\hline PLZ & 184 & 4.168 & 0.836 & -0.894 & 0.642 & 0.237 & $0.000^{* *}$ & 0.812 & $0.000 * *$ \\
\hline $\mathrm{CHO}$ & 184 & 4.174 & 0.888 & -1.106 & 1.349 & 0.248 & $0.000^{* *}$ & 0.798 & $0.000 * *$ \\
\hline REV & 184 & 3.745 & 1.166 & -0.763 & -0.198 & 0.233 & $0.000^{* *}$ & 0.859 & $0.000^{* *}$ \\
\hline WOM & 184 & 3.848 & 0.974 & -0.657 & 0.125 & 0.231 & $0.000^{* *}$ & 0.865 & $0.000^{* *}$ \\
\hline EA1 & 184 & 3.832 & 1.066 & -0.617 & -0.411 & 0.215 & $0.000^{* *}$ & 0.864 & $0.000 * *$ \\
\hline EA2 & 184 & 3.853 & 1.038 & -0.859 & 0.289 & 0.263 & $0.000^{* *}$ & 0.85 & $0.000^{* *}$ \\
\hline EA3 & 184 & 3.908 & 1.012 & -0.772 & 0.082 & 0.237 & $0.000^{* *}$ & 0.853 & $0.000^{* *}$ \\
\hline EA4 & 184 & 3.918 & 0.952 & -0.643 & 0.223 & 0.235 & $0.000^{* *}$ & 0.872 & $0.000^{* *}$ \\
\hline
\end{tabular}

Note: ${ }^{*} p<0.05^{* *} p<0.01$

The correlation analysis is presented in Table 6. The square roots of the construct correlations are smaller than their AVEs (Gefen,
Straub, \& Boudreau, 2000). This confirms the validity of the discriminant method. 
Table 6 - Correlations and square roots of the AVEs

\begin{tabular}{|l|c|c|c|c|}
\hline & CL & EA & PQ & VS \\
\hline CL & 0.89 & & & \\
\hline EA & 0.732 & 0.835 & & \\
\hline PQ & 0.439 & 0.508 & 0.711 & \\
\hline VS & 0.678 & 0.672 & 0.495 & 0.888 \\
\hline
\end{tabular}

\subsection{Results of the PLS analysis}

Given that there were 184 respondents, following Hair et al. (2011), 5,000 samples were used to perform bootstrapping to ensure that path coefficients were significant. The PLS results are shown in Figure 2 . The $\mathrm{R}^{2}$ value of the structure model was 0.474 , and the adjusted value of $R^{2}$ was 0.468 . Therefore, this is a "moderate" model (Hair et al., 2011). All three factors (perceived quality, emotional attachment, visitor satisfaction) showed a significant relationship with conative loyalty, which supports $\mathrm{H} 1, \mathrm{H} 2, \mathrm{H} 3$, and $\mathrm{H} 4$. The indirect effects of PLS are shown in Table 4. Emotional attachment and perceived quality have a significant relationship with conative loyalty, which supports $\mathrm{H} 5$ and $\mathrm{H} 6$.

Table 7 - Hypothesis testing

\begin{tabular}{|l|c|c|c|}
\hline Hypothesis & Path & Standardised Path Coefficients & t-value (bootstrap) \\
\hline $\mathrm{H} 1$ & $\mathrm{EA} \rightarrow \mathrm{VS}$ & 0.566 & 8.619 \\
\hline $\mathrm{H} 2$ & $\mathrm{PQ} \rightarrow \mathrm{VS}$ & 0.208 & 3.384 \\
\hline $\mathrm{H} 3$ & $\mathrm{PQ} \rightarrow \mathrm{CL}$ & 0.137 & 2.159 \\
\hline $\mathrm{H} 4$ & $\mathrm{VS} \rightarrow \mathrm{CL}$ & 0.61 & 9.679 \\
\hline $\mathrm{H} 5$ & $\mathrm{EA} \rightarrow \mathrm{VS} \rightarrow \mathrm{CL}$ & 0.345 & 5.182 \\
\hline $\mathrm{H} 6$ & $\mathrm{PQ} \rightarrow \mathrm{VS} \rightarrow \mathrm{CL}$ & 0.127 & 3.682 \\
\hline
\end{tabular}

Note: Loadings are significant at $p<.05 R^{2}$ (visitor satisfaction) $=0.484 ; R^{2}$ (conative loyalty) $=0.474$

Figure 2 - Results of the PLS analysis

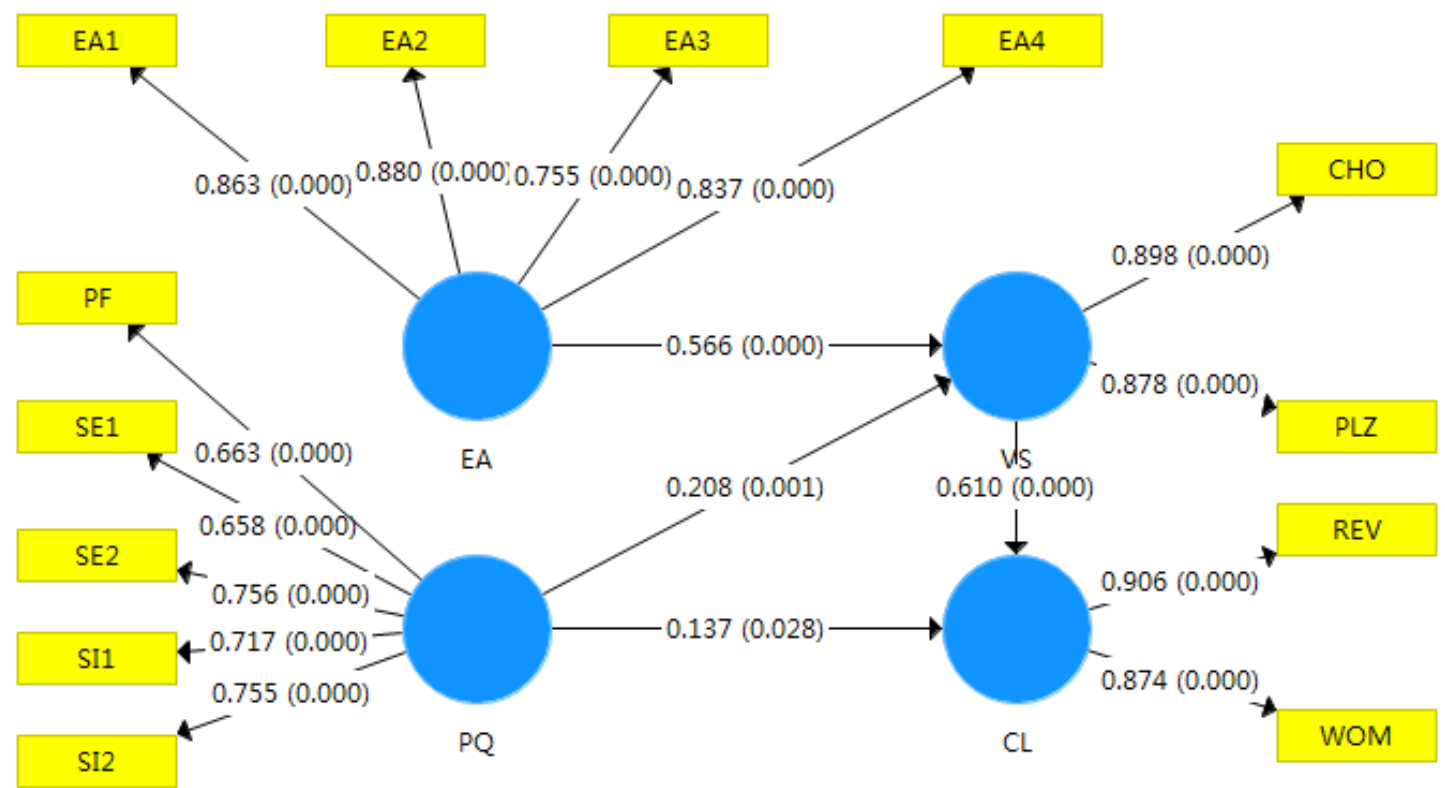

The results in Table 7 and Figure 3 indicate that emotional attachment has a positive impact on visitors' satisfaction $(\mathrm{H} 1 ; \beta$ $=0.566 ; p<0.05)$. Visitor satisfaction was positively affected by perceived quality $(\mathrm{H} 2 ; \beta=0.208 ; \mathrm{p}<0.05)$, and conative loyalty is positively affected by perceived quality $(H 3 ; \beta=0.137 ; p<$ 0.05). Furthermore, visitor satisfaction positively affected conative loyalty $(\mathrm{H} 4 ; \beta=0.61 ; \mathrm{p}<0.05)$. Emotional attachment is a mediator variable that affects the connection between conative loyalty and perceived quality $(\mathrm{H} 5: \mathrm{EA} \rightarrow \mathrm{VS} \rightarrow \mathrm{CL}, \beta=$
$0.345 ; p<.05)$. The relationship between conative loyalty and perceived quality is affected by visitor satisfaction, which is a mediating variable $(\mathrm{H} 6: \mathrm{PQ} \rightarrow \mathrm{VS} \rightarrow \mathrm{CL}, \beta=0.127 ; \mathrm{p}<.05)$. The direct path coefficient from perceived quality to conative loyalty is 0.137 . However, the indirect path coefficient is 0.127 . The latter is smaller than the former, which means that the influence of perceived quality on conative loyalty is weakened by the mediator. 
Figure 3 - Results of the PLS analysis for the model

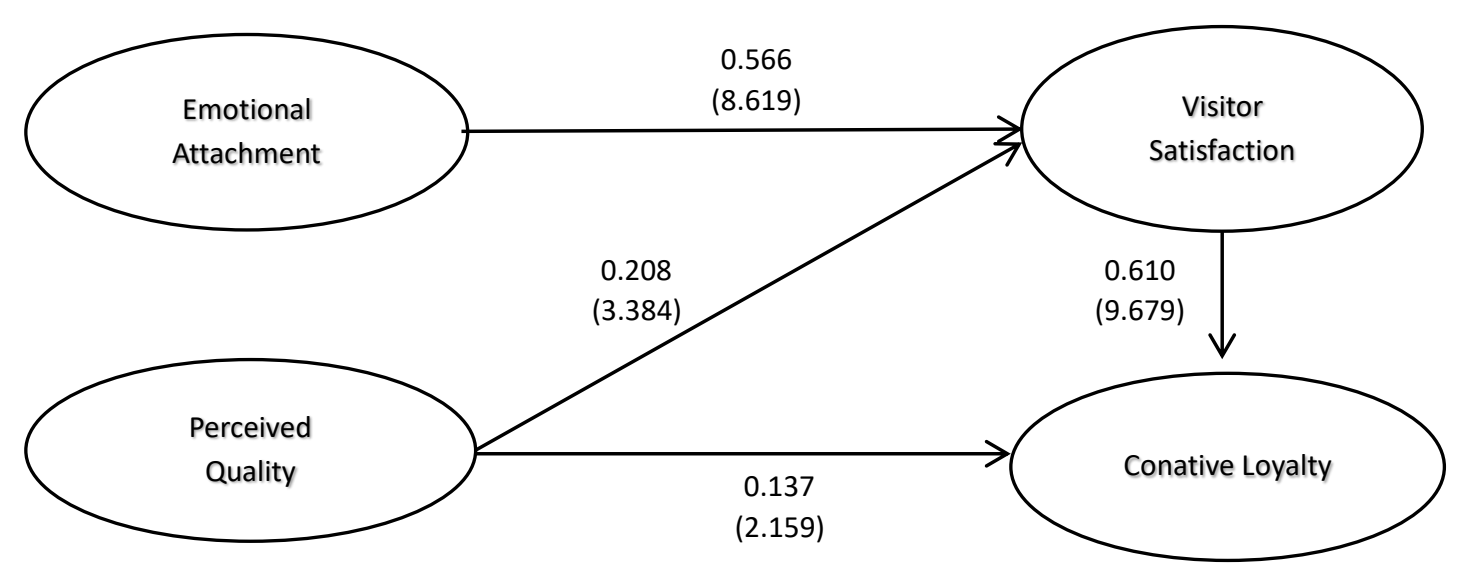

\section{Theoretical and practical implications}

Based on the results above, EA and PQ significantly affect VS, and $E A, P Q$, and VS are all connected to the $\mathrm{CL}$. These results indicate that the better visiting experience visitors have during a museum visit, the more likely they are to become loyal customers towards the destination (Campón-Cerro, HernandezMogollón, \& Alves, 2016; Chi \& Qu, 2008; Wu, 2016). Ultimately, the desire to revisit can be enhanced (Grappi \& Montari, 2011). As the public "attention" generated by the "attraction" of museums is the source of the realization of the social value of museums, the extent to which the social value is realized is determined both by the number of visitors and by public "attention." Attention includes public satisfaction, trust, and loyalty.

Moreover, the intangible and tangible qualities of AMGX strongly affect visitors' choices. As Chi and Qu remark, when a person perceives products and services in a certain way, this may directly change their expectations of the associated experience (2008). Tangibility can be easily defined as the museum's setting and human resource management. To illustrate, the measurement scale of $P Q$ in this research converts staff's prompt assistance, museum environment, facilities, and so forth. In contrast, the enthusiasm of museum staff and the communicative function of display can be categorized as part of an intangible aspect. Furthermore, as the museum provides material evidence related to the production, life, culture, and natural environment of local Guangxi citizens, it contains a large amount of cultural resources and a huge amount of information, which are also the source of the museum's cultural power. However, the cultural power of museums is not static. They not only protect the physical form of culture but also activate a large amount of cultural information, thus nourishing cultural inheritance and innovation. These are significant factors influencing the perceived quality of AMGX.

This study mainly contributes by applying emotional attachment (EA) to museum tourism. The establishment of an emotional connection is based on Zhuang cultural inheritance. Visitors' yearning, expectations, and curiosity about the culture stimulate this emotional connection. Part of what makes cultural objects so important is that they offer useful cultural lessons for the present and future. To some extent, all cultural elements, including objects, await the moment they are reused. The energy of the objects and the efforts of the collectors and custodians make the museum vibrant. Thinking and communicating behaviors, emotional attachment, and decisionmaking are brought together and recreated in the museum, which benefits everyone's behavior and thinking. Laws and regulations are necessary for widen educational reform, share high-quality educational resources, and pass on traditional culture. Museums are essential in national educational reform.

\section{Conclusion}

The museum expresses its cultural connotations, which can combine specific cultural traditions and effective emotional expression through different forms of demonstration. Provoking positive or negative psychological resonance with the audience, such as emotional attachment, perceived quality, which directly or indirectly affects the conative function and viewing the emotions of the visitors. By employing the affective connection, which is combined with service quality and satisfaction, and to develop a research model in the context of the museum industry. For presenting a quantitative study of four constructs: emotional attachment, visitor satisfaction, perceived quality and conative loyalty, visitors (both locals and nonlocals) are involved in the data collection, and six hypotheses are positively supported. In the museum, using emotional power can uncover the hidden significance and value information of cultural relics in the collection. so that changes in the satisfaction of visitors to the museum and ultimately promote the generation and increase of visiting behavior.

\section{Limitations and further studies}

The limitations of this research are in the foundation for future research. First, as the survey was limited to visitors to one specific anthropology museum in the capital of Guangxi, the sample and results may not be generalizable. Furthermore, as the research focuses on one cultural museum, the results cannot be applied more generally to the field of museum 
tourism. Future studies on other museums could help determine whether different visitors and museum samples produce similar results. Our study also only examines three antecedent variables of conative loyalty: emotional attachment, perceived quality, and visitor satisfaction. However, many other variables can predict the behavioral intentions of consumers (museum visitors). Some researchers have tested models of the decision-making process. Examples include Tiets' (1993) threedimensional process (selection of product, variety of shop, and purchase point), and the TSRV formula introduced by Olach (1999). In museum tourism, the incentives/attributes of customer/visitor loyalty remain underexplored, and regional distinctions may lead to differences. Thus, these areas are worth future investigation.

\section{References}

Afthanorhan, W. (2013). A Comparison of partial least square structural equation modeling (pls-sem) and covariance based structural equation modeling (cb-sem) for confirmatory factor analysis. International Journal of Engineering Science and Innovative Technology, 2(5), 198205.

Akama, J. S., \& Kieti, D. M. (2002). Measuring tourist satisfaction with Kenya's wildlife safari: A case of Tsavo West National Park. Tourism Management, 23, 73-81. https://doi.org/10.1016/s02615177(02)00044-4

Albert, N., Merunka, D., \& Valette-Florence, P. (2008). When consumers love their brands: Exploring the concept and its dimensions. Journal of Business Research, 61(10), 1062-1075. https://doi.org/10.1016/j.jbusres.2007.09.014

Armstrong, R. W., Mok, C., Go, F. M., \& Chan, A. (1997). The importance of cross-cultural expectations in the measurement of service quality perceptions in the hotel industry. International Journal of Hospitality Management, 16(2), 181-190. https://doi.org/10.1016/S02784319(97)00004-2

Atilgan, E., Akinci, S., \& Aksoy, S. (2003). Mapping service quality in the tourism industry. Managing Service Quality, 13(5), 412-422. https://doi.org/10.1108/09604520310495877

Back, K. J. (2005). The effects of image congruence on customers' brand loyalty in upper middle-class hotel industry. Journal of Hospitality and $\begin{array}{lll}\text { Tourism Research, 29(4), 448-467. } & \end{array}$ https://doi.org/10.1177/1096348005276497

Bagozzi, R. P. (1992). The self-regulation of attitudes, intentions, and behavior. Social Psychology Quarterly, 55(2), 178-204. https://doi.org/10.2307/2786945

Baker, D. A., \& Crompton, J. L. (2000). Quality, satisfaction and behavioral intentions. Annals of Tourism Research, 27(3), 785-804. https://doi.org/10.1016/S0160-7383(99)00108-5

Ball, D., \& Tasaki, L. H. (1992). The role and measurement of attachment in consumer behavior. Journal of Consumer Psychology, 1(2), 155-172. https://doi.org/10.1016/S1057-7408(08)80055-1

Bartholomew, K., \& Horowitz, L. M. (1991), Attachment styles among young adults: A test of a four-category model. Journal of Personality and Social Psychology, 61(2), 226-244. https://doi.org/10.1037//00223514.61.2.226

Bitner, M. J., \& Hubbert, A. R. (1994). Encounter satisfaction versus overall satisfaction versus quality: The customer's voice. In Roland T. Rust and Richard L. Oliver (Eds.) Service Quality: New Directions in Theory and Practice (pp. 72-94). Thousand Oaks, CA: Sage.

Boylan, P. J. (2010). International Council of Museums (ICOM). In Encyclopedia of library and information sciences (pp. 2873-2880).

Brucks, M., Zeithaml, V. \& Naylor, G. (2000). Price and brand name as indicators of quality dimensions for consumer durables. Journal of the Academy of Marketing Science, 28(3), 359-374.

\section{https://doi.org/10.1177/0092070300283005}

Buhalis, D. (2000). Marketing the competitive destination in the future. Tourism Management, 21(1), 97-116. https://doi.org/10.1016/S02615177(99)00095-3

Campón-Cerro, A. M., Hernandez-Mogollón, J. M., \& Alves, H. (2016). Sustainable improvement of competitiveness in rural tourism destinations: The quest for tourist loyalty in Spain. Journal of Destination Marketing and Management, http://dx.doi.org/10.1016/j.jdmm.2016.04.005i

Carroll, B., \& Ahuvia, A. (2006). Some antecedents and outcomes of brand love. Marketing Letters, 17(2), 79-89.

Carver, C. S., \& Scheier, M. F. (1990). Origins and functions of positive and negative affect: A control-process view. Psychological Review, 97(January), 19-35. https://doi.org/10.1037/0033-295X.97.1.19

Chen, C.-F., \& Tsai, D. (2007). How destination image and evaluative factors affect behavioral intentions? Tourism Management, 28, 11151122. https://doi.org/10.1016/j.tourman.2006.07.007

Chew, E., \& Jahari, S. (2014). Destination image as a mediator between perceived risks and revisit intention: A case of post-disaster Japan. Tourism Management, 40, 382-393. https://doi.org/10.1016/j.tourman.2013.07.008

Chi, C. G. Q., \& Qu, H. (2008). Examining the structural relationships of destination image, tourist satisfaction and destination loyalty: An integrated approach. Tourism Management, 29, 624-636. https://doi.org/10.1016/j.tourman.2007.06.007

Chin, W.W., Marcolin, B.L., \& Newsted, P.R. (2003). A partial least squares latent variable modeling approach for measuring interaction effects: Results from a Monte Carlo simulation study and an electronicmail emotion/adoption study. Information Systems Research, 14(2), 189-217.

Churchill, G. A., \& Surprenant, C. (1982). An investigation into the determinants of customer satisfaction. Journal of Marketing Research, 19(November), 491-504. https://doi.org/10.2307/3151722

Cole, S. T., \& Illum, S. F. (2006). Examining the mediating role of festival visitors' satisfaction in the relationship between service quality and behavioral intentions. Journal of Vacation Marketing, 12(2), 160-173. https://doi.org/10.1177/1356766706062156

Cooper, C., Fletcher, J., Gilbert, D., \& Wanhill, S. (1993). In Tourism: Principles and practice. Harlow: Longman Scientific \& Technical.

Cronin, J. J., \& Taylor, S. A. (1992). Measuring service quality: A reexamination and extension. Journal of Marketing 56 (July), 55-68. https://doi.org/10.1177/002224299205600304

Dick, A.S., Basu, K. (1994). Customer loyalty: Toward an integrated conceptual framework. Journal of the Academy of Marketing Science, 22(2), 99-113. https://doi.org/10.1177/0092070394222001

Dimanche, F., \& Havitz, M. (1995). Consumer behavior and tourism. Journal of Travel and Tourism Marketing, 3(3), 37-57.

Drezner, Z., \& Zerom, O. T. D. (2010). A modified Kolmogorov-Smirnov test for normality. Mpra Paper,39(4), 693-704.

Eagly, A. H., \& Chaiken, S. (1993). The psychology of attitudes. Fort Worth, TX: Harcourt, Brace.

Evanschitzky, H., \& Wunderlich, M. (2006). An examination of moderator effects in the four-stage loyalty model. Journal of Service Research, 8(4), 330-345. https://doi.org/10.1177/1094670506286325 Fornell, C. R., \& Larcker, D. F. (1981). Evaluating structural equation models with unobservable variables and measurement error. Journal of Marketing Research, 18(3), 375-381. https://doi.org/10.1177/002224378101800104

George, B. P., \& George, B. P. (2004). Past visit and the intention to revisit a destination: Place attachment as the mediator and novelty seeking as the moderator. Journal of Tourism Studies, 15(2), 51-66.

Gefen, D., Straub, D., \& Boudreau, M. (2000). Structural equation modeling techniques and regression: Guidelines for research practice. Communications of the Association for Information Systems, 7(7), 1-78. https://doi.org/10.17705/1CAIS.00407 
Gross, M. J., \& G. Brown. (2008). An empirical structure model of tourists and places: Progressing involvement and place attachment into tourism. Tourism Management, 29(6), 1141-1151. https://doi.org/10.1016/j.tourman.2008.02.009

Gotlieb, J. B., Grewal, D., \& Brown, S. W. (1994). Satisfaction and perceived quality: Complementary or divergent constructs? Journal of Applied Psychology, 79(6), 875-885. https://doi.org/10.1037/00219010.79.6.875

Gronroos, C. (1984). A service quality model and its marketing implications. European Journal of Marketing, 18(4), 36-44. https://doi.org/10.1108/EUM0000000004784

Giuliani, M.V., \& R. Feldman. (1993). Place attachment in a developmental and cultural context. Journal of Environmental Psychology, 13(3), 267-274. https://doi.org/10.1016/S02724944(05)80179-3

Gursoy, D., Chen, S., J, G., \& Chi, C. (2014). Theoretical examination of destination loyalty formation. International Journal of Contemporary Hospitality Management, 26(5), 809-827. https://doi.org/10.1108/IJCHM-12-2013-0539

Haenlein, M., \& Kaplan, A. M. (2004). A beginner's guide to partial least squares analysis. Understanding Statistics, 3(4), 283-297. https://doi.org/10.1207/s15328031us0304_4

Hair, J.F., Ringle, C.M., \& Sarstedt, M. (2011). PLS-SEM: Indeed a silver bullet. Journal of Marketing Theory and Practice, 19(2), 139-151. https://doi.org/10.2753/mtp1069-6679190202

Han, H., Lee, S., \& Hyun, S. S. (2019). Role of internal and external museum environment in increasing visitors' cognitive/affective/healthy experiences and loyalty. International journal of environmental research and public health, 16(22), 4537.

Hazan, C., \& Shaver, P. R. (2000). Adult romantic attachment: Theoretical developments, emerging controversies, and unanswered questions. Review of General Psychology, 4(2), 132-154. https://doi.org/10.1037/1089-2680.4.2.132

Hazan, C., \& Shaver, P. R. (1994), Attachment as an organizational framework for research on close relationships. Psychological Inquiry, 5(1), 1-22. https://doi.org/10.1207/s15327965pli0501_1

Hidalgo, M. C., \& Hernandez, B. (2001). Place attachment: Conceptual and empirical questions. Journal of Environmental Psychology, 21(3), 273-281. https://doi.org/10.1006/jevp.2001.0221

Hosany, S., \& Gilbert, D. (2010). Measuring tourists' emotional experiences toward hedonic holiday destinations. Journal of Travel Research, $49(4)$, https://doi.org/10.1177/0047287509349267

Hsieh, C. M. (2010). Roles of motivations, past experience, perceptions of. service quality, value and satisfaction in museum visitors' loyalty. Michigan State University.

Hsieh, L.-F., Lin, L.-H., \& Lin, Y.-Y. (2008). A service quality measurement architecture for hot spring hotels in Taiwan. Tourism Management, 29, 429-438. https://doi.org/10.1016/j.tourman.2007.05.009

Hughes, K. (1991). Tourist satisfaction: A guided 'cultural' tour in North Queensland. Australian Psychologist, 26(3), 166-171. https://doi.org/10.1080/00050069108257243

Hui, T. K., Wan, D., \& Ho, A. (2007). Tourists' satisfaction, recommendation and revisiting Singapore. Tourism Management, 28, 965-975. https://doi.org/10.1016/j.tourman.2006.08.008

Jacoby, Jacob, \& Chestnut, Robert W. 1978. Brand loyalty measurement and management. New York: John Wiley.

Kang, J. H., Jang, J. C., \& Jeong, C. (2018). Understanding museum visitor satisfaction and revisit intentions through mobile guide system: Moderating role of age in museum mobile guide adoption. Asia Pacific Journal of Tourism Research, 23(2), 95-108.

Kim, A. K., \& Brown, G. (2012). Understanding the relationships between perceived travel experiences, overall satisfaction, and destination loyalty. Anatolia, 23(3), 328-347. https://doi.org/10.1080/13032917.2012.696272
Kim, K., Hallab, Z., \& Kim, J. N. (2012). The moderating effect of travel experience in a destination on the relationship between the destination image and the intention to revisit. Journal of Hospitality Marketing Management, 21, 486-505. https://doi.org/10.1080/19368623.2012.626745

Kyle, G., Graefe, A., Manning, R., \& Bacon, J. (2004). Effect of activity involvement and place attachment on recreationists' perceptions of setting density. Journal of Leisure Research, 36(2), 209-231. https://doi.org/10.1080/00222216.2004.11950020

Lam, S. Y., Shankar, V., Erramilli, M. K., \& Murthy, B. (2004). Customer value, satisfaction, loyalty, and switching costs: An illustration from a business-to-business service context. Journal of the Academy of Marketing Science, 32, 293-311. https://doi.org/10.1177/0092070304263330

Lazarus, Richard S. 1991. Emotion and adaptation. New York: Oxford University Press.

Lee, J., Kyle, G. T., \& Scott, D. (2012). The mediating effect of place attachment on the relationship between festival satisfaction and loyalty to the festival hosting destination. Journal of Travel Research, 51(6), 754-767. https://doi.org/10.1177/0047287512437859

Lee, S. Y., Petrick, J. F., \& Crompton, J. (2007). The roles of quality and intermediary constructs in determining festival attendees' behavioral intention. Journal of Travel Research, 45(4), 402-412. https://doi.org/10.1177/0047287507299566

Lilliefors, H. (1967). On the Kolmogorov-Smirnov test for normality with mean and variance unknown. Publications of the American Statistical Association, 62(318), 399-402.

Malhotra, N. K. (2004). Marketing research: An applied orientation (4th ed). NJ: Prentice Hall.

Manzo, L. C. (2003). Relationships to non-residential places: Towards a reconceptualization of attachment to place. Journal of Environmental Psychology, 23(1), 47-61.

Mathies, C., \& Gudergan, S. (2012). Do status levels in loyalty programs change customers' willingness to pay? Journal of Revenue and Pricing Management, 11(3), 274-288. https://doi.org/10.1057/rpm.2012.13

McLean, F. (1994). Services marketing: The case of museums. Services Industrial Journal, 14(2), 190-203. https://doi.org/10.1080/02642069400000022

McLean, F. (1997). Marketing the museum. New York: Routledge. https://doi.org/10.4324/9780203033661

Moore, R. L., \& Graefe, A. R. (1994). Attachments to recreation settings: The case of rail-trail users. Leisure Sciences, 16(1), 17-31. https://doi.org/10.1080/01490409409513214

Morais, D. B., \& Lin, C. H. (2010). Why do first-time and repeat visitors patronize a destination? Journal of Travel and Tourism Marketing, 27(2), 193-210. https://doi.org/10.1080/10548401003590443

Official website of Anthropology Museum of Guangxi, Introduction. http://www.amgx.org/eng/

Olach, Z. (1999). A marketing szemlélete és gyakorlata (Theory and practice of marketing). Ligatura Kft. p. 268.

Oliver, Richard L. (1980). A cognitive model of the antecedents and consequences of satisfaction decisions. Journal of Marketing Research 17, 460-469. https://doi.org/10.2307/3150499

Oliver, Richard L. (1997). Satisfaction: A behavioral perspective on the customer. Boston: McGraw-Hill.

Oliver, Richard L. (1999). Whence consumer Loyalty. Journal of Marketing 63(Special Issue), 33-44.

Oliver, R. (1980). A cognitive model of the antecedents and consequences of satisfaction decisions. Journal of Marketing Research, 17, 460-469. https://doi.org/10.2307/3150499

Parasuraman, A., Zeithaml, V. A., \& Berry, L. L. (1988). SERVQUAL: A multiple-item scale for measuring consumer perceptions of service quality. Journal of Retailing, 64, 12-40. https://doi.org/10.1016/07376782(88)90045-8

Park, C.W., \& MacInnis, D.J. (2006). What's in and what's out: Questions 
on the boundaries of the attitude construct. Journal of Consumer Research, 33(6), 16-18. https://doi.org/10.1086/504122

Park, C.W., Maclnnis, J., \& Priester, J. (2006), Beyond attitudes: Attachment and consumer behavior. Seoul Journal of Business, 12(2), 336.

Patterson, Paul G. (2000.) A contingency approach to modeling satisfaction with management consulting services. Journal of Service Research 3, 138-153. https://doi.org/10.1177/109467050032003

Paulssen, M., \& Fournier, S. (2007). Attachment security and the strength of commercial relationships: A longitudinal study. Discussion Paper No. 50, Department of Business and Economics, Humboldt University, Berlin.

Pedersen, P., \& Nysveen, H. (2001). Shopbot banking: An exploratory study of customer loyalty effects. International Journal of Bank Marketing, 19(4), 146-155. https://doi.org/10.1108/02652320110392518

Phaswana-Mafuya, N., \& Haydam, N. (2005). Tourists' expectations and perceptions of the Robben Island Museum-a world heritage site. Museum Management and Curatorship, 20(2), 149-169. https://doi.org/10.1080/09647770500502002

Raajpoot, N., Koh, K., \& Jackson, A. (2010). Developing a scale to measure service quality: An exploratory study. International Journal of Arts Management, 12(3), 54-69. Retrieved from www.jstor.org/stable/41065028

Radder, L., \& Han, X. (2015). An examination of the museum experience based on Pine and Gilmore's experience economy realms. Journal of Applied Business Research, 31(2), 455.

Rowley, J. (1999). Measuring total customer experience in museums. International Journal of Contemporary Hospitality Management, 11(6), 303-308. https://doi.org/10.1108/09596119910281801

Simpson, M. P., \& Siquaw, J. (2008). Destination word-of-mouth: The role of traveler type, residents, and identity salience. Journal of Travel Research. 47(November), 167-182. https://doi.org/10.1177/0047287508321198

Siu, N. Y. M., Zhang, T. J. F., Dong, P., \& Kwan, H. Y. (2013). New service bonds and customer value in customer relationship management: The case of museum visitors. Tourism Management, 36, 293-303.

Sulkaisi, N. (2020, March). Analysis of Service Quality on Tourist Satisfaction and Tourist Loyalty Study at Adityawarman Museum. In 4th Padang International Conference on Education, Economics, Business and Accounting (PICEEBA-2 2019) (pp. 398-406). Atlantis Press.

Sun, X., Chi, C. G. Q., \& Xu, H. (2013). Developing destination loyalty: The case of Hainan Island. Annals of Tourism Research, 43(10), 547-577. https://doi.org/10.1016/j.annals.2013.04.006

Tasci, A. D. A. (2011). Destination branding and positioning. In: Y. Wang, and A. Pizam (Eds.), Destination marketing and management: theories and applications (pp. 113-129). Cabi.

Taylor, S. A., \& Baker, T. L. (1994). An assessment of the relationship between service quality and customer satisfaction in the formation of customers' purchase intentions. Journal of Retailing 70(2), 163-178. https://doi.org/10.1016/0022-4359(94)90013-2

Thomson, M. (2006). Human brands: Investigating antecedents to consumers' strong attachments to celebrities. Journal of Marketing, 70(3), 104-119. https://doi.org/10.2307/30162104

Thomson, M., \& Johnson, A. R. (2006). Marketplace and personal space: Investigating the differential effects of attachment style across relationship contexts. Psychology and Marketing, 23(8), 711-726. https://doi.org/10.1002/mar.20125

Thomson, M., Maclnnis, D. J., \& Park, C. W. (2005). The ties that bind: Measuring the strength of consumers' emotional attachments to brands. Journal of Consumer Psychology, 15(1), 77-91. https://doi.org/10.1207/s15327663jcp1501_10

Tietz, B. (1993). Zukunftsstrategien für Handelsunternehmen. Frankfurt am Main: Deutscher Verlag.

Tribe, J., \& Snaith, T. (1998). From SERVQAL to HOLSAT: Holiday satisfaction in Varadero, Cuba. Tourism Management, 19(1), 22-34. https://doi.org/10.1016/S0261-5177(97)00094-0

Vesci, M., Conti, E., Rossato, C., \& Castellani, P. (2020). The mediating role of visitor satisfaction in. the relationship between museum experience and word of mouth: evidence from Italy. The TQM Journal, 33(1), 141-162. https://doi.org/10.1108/TQM-02-2020-0022

Vida, I., \& Reardon, J. (2008). Domestic consumption: Rational, affective or normative choice. Journal of Consumer Marketing, 25(1), 34-44. https://doi.org/10.1108/07363760810845390

Weaver, D. B., \& Lawton, L. J. (2011). Visitor loyalty at a private South Carolina protected area. Journal of Travel Research, 50(3), 335-346. https://doi.org/10.1177/0047287510362920

Williams, D. R., \& Vaske, J. J. (2003). The measurement of place attachment: Validity and generalizability of a psychometric approach. Forest Science, 49(6), 830-840. https://doi.org/10.1016/S13899341(03)00041-8

Wong, S. C. K., \& Ko, A. (2009). Exploratory study of understanding hotel employees' perception on work-life balance issues. International Journal of Hospitality Management, 28, 195-203.

Woodside, A. G., Frey, L. L., \& Daly, R. T. (1989). Linking service quality, customer satisfaction, and behavioral intentions. Journal of Health Care Marketing, 9 (4), 5-17.

Wu, C. W. (2015). Foreign tourists' intentions in visiting leisure farms. Journal of Business Research, 68(4), 757-762. https://doi.org/10.1016/j.jbusres.2014.11.024

Wu, H. C., \& Li, T. (2015). An empirical study of the effects of service quality, visitor satisfaction, and emotions on behavioral intentions of visitors to the museums of Macau. Journal of Quality Assurance in Hospitality \& Tourism, 16(1), 80-102.

Yoon, Y., \& Uysal, M. S. (2005). An examination of the effects of motivation and satisfaction on destination loyalty: A structural model. Tourism Management, 26(1), 45-56. https://doi.org/10.1016/j.tourman.2003.08.016

Yüksel, A., \& Yüksel, F. (2001). The expectancy-disconfirmation paradigm: A critique. Journal of Hospitality and Tourism Research, 25(2), 107-131. https://doi.org/10.1177/109634800102500201

Yuksel, A., Yuksel, F., \& Bilim, Y. (2010). Destination attachment: Effects on customer satisfaction and cognitive, affective and conative loyalty. Tourism Management, 31(2), 274-284. https://doi.org/10.1016/j.tourman.2009.03.007

Zeithaml, V., Berry, L., \& Parasuraman, A. 1996. The behavioral consequences of service quality. Journal of Marketing 60(April), 31-46. https://doi.org/10.1177/002224299606000203

Zhang, H., Fu, X., Cai, L. A., \& Lu, L. (2014). Destination image and tourist loyalty: A meta-analysis. Tourism Management, 40, 213-223. https://doi.org/10.1016/j.tourman.2013.06.006 